\title{
Topography of lectin binding sites in celiac sprue
}

\author{
HUGH J FREEMAN, MD, FRCPC, FACP
}

HJ FreEman. Topography of lectin binding sites in celiac sprue. Can J Gastroenterol 1992;6(5):271-276. Lectins are ubiquitious, naturally occurring proteins largely derived from plants that are present in the human diet. They are released from food during mastication and digestion to remain biologically intact during passage through the small intestine. In this study, the topographic distribution of binding sites in the small intestine for six different lectins (derived from wheat germ, castor bean, gorse, horsegram, jackbean and peanut) were explored in 16 patients with celiac sprue along with controls. For each lectin, the pattern of binding in the small intestinal biopsy specimens was distinct and specifically inhibited by a different carbohydrate residue. Lectin labelling patterns were different for both controls and celiac patients. In addition, the epithelial cell membrane surface and goblet cells exhibited a gradient of fluorescence intensity along the crypt-villus column. This gradient appeared to parallel the degree of enterocytic differentiation consistent with the concept that sequential addition of sugar residues to form completed oligosaccharide side chains occurs with enterocytic differentiation and maturation. These results also suggest that the process of epithelial cellular differentiation, although present in celiac enterocytes, is altered substantially.

Key Words: Carbohydrate histochemistry, Celiac sprue, Epithelial cell differentiation, Glycoproteins, Goblet cell mucins, Lectins

\section{Topographie des sites de liaison de la lectine en présence de sprue coeliaque}

RÉSUMÉ: Les lectines sont des protéines naturelles omniprésentes, dérivées principalement de plantes utilisées dans l'alimentation humaine. Elles sont libérées à partir des aliments durant la mastication et la digestion et demeurent biologiquement intactes au cours du passage vers le petit intestin. Dans cette étude, la distribution topographique des sites de liaison au niveau du petit intestin pour six lectines différentes (tirées de germe de blé, de graines de ricin, d'ajoncs, de pois doliques de type asperge, de pois sabre et d'arachides) a été étudiée chez 16 patients présentant une sprue coeliaque et chez des patients témoins. Pour chaque lectine, le mode de liaison au niveau des spécimens de biopsie du petir

Department of Medicine (Gastroenterology), University of British Columbia and University Hospital, Vancouver, British Columbia

Correspondence and reprints: Dr Hugh Freeman, Head, Gastroenterology, ACU F-137, University Hospital (UBC site), 2211 Wesbrook Mall, Vancouver, British Columbia V6T IW5. Telephone (604) 822-7216

Received for publication April 22, 1992. Accepted July 15, 1992
【 ECTINS ARE UBIQUITOUS, NATURally occurring proteins and glycoproteins largely derived from plants (1). Interestingly, lectins have been detected in foods that are becoming increasingly important in diets of the health conscious consumer including a number of staples, such as potatoes, peas, beans, soybeans, various nuts, tomatoes and wheat germ (2). Lectins may be released from these dietary substances during mastication and/or digestion and may remain biologically intact during passage, even into the distal small intestine (3). Some lectins are potent biological agents that bind to specific sugar residues, agglutinate fetal and neoplastic cells, inhibit in vivo and in vitro tumour growth and stimulate lymphocyte proliferation (1).

Celiac sprue (celiac disease, glutensensitive enteropathy) is a disorder characterized by a typical, although not specific, small intestinal mucosal lesion that is improved with restriction of dietary gluten (4). Impaired absorption of one or more nutrients may also occur (4). Although the primary defect still requires elucidation, gluten may initiate cell toxicity by acting as a lectin and binding to defective brush border membrane components in genetically predisposed patients (5). An identical lectin hypothesis (5) has been developed for soy protein intolerance, a small intestinal mucosal disorder, clinically and histologically indistinguishable from celiac sprue (6). 
intestin était distinct et spécifiquement inhibé par différents résidus glucidiques. Les modes de marquage de la lectine ont été différents chez les témoins et chez les patients atteints. En outre, la membrane cellulaire épithéliale de surface et les cellules calciformes faisaient état d'un gradient d'intensité à la fluorescence le long des villosités. Ce gradient a semblé correspondre au degré de différentiation entérocytaire, conformément à l'hypothèse selon laquelle l'addition séquentielle de résidus de sucre pour former des chaînes latérales d'oligosaccharides complètes se produit en présence de différentiation et de maturation entérocytaires. Ces résultats suggèrent également que le processus de différentiation cellulaire épithéliale, bien que présent au niveau des entérocytes coeliaques est considérablement altéré.

Given their potentially diverse role in both health and disease, this study explored the cellular localization and topographic distribution of lectin bind-

\section{TABLE 1}

Patients with celiac sprue

\begin{tabular}{|c|c|c|c|c|}
\hline Patient & Age (years) & Sex & Diarrhea & Comment \\
\hline 1 & 35 & Male & 6 months & $\begin{array}{l}\text { Immune-complex } \\
\text { glomerulonephritis (7); } \\
\text { dermatitis herpetiformis } \\
\text { hypothyroidism }\end{array}$ \\
\hline 2 & 70 & Male & 2 months & Subsequent Iymphoma (8) \\
\hline 3 & 73 & Female & See text & Lymphoma (9) \\
\hline 4 & 34 & Female & 3 months & \\
\hline 5 & 31 & Male & 18 months & \\
\hline 6 & 41 & Female & See text & Hypothyroidism \\
\hline 7 & 59 & Male & 10 years & \\
\hline 8 & 66 & Male & 10 months & \\
\hline 9 & 29 & Female & 6 months & \\
\hline 10 & 62 & Female & 4 years & \\
\hline 11 & 41 & Male & 1 month & \\
\hline 12 & 55 & Male & 2 years & \\
\hline 13 & 22 & Female & 7 months & \\
\hline 14 & 70 & Female & 11 months & \\
\hline 15 & 39 & Female & 8 months & \\
\hline 16 & 68 & Female & 5 months & Dermatitis herpetiformis \\
\hline
\end{tabular}

\section{TABLE 2}

\section{Carbohydrate specificity of lectins}

\begin{tabular}{|c|c|c|c|c|}
\hline Lectin & Plant origin & Abbreviation & $\begin{array}{l}\text { Major sugar } \\
\text { specificities * }\end{array}$ & Binding inhibitor ${ }^{\star}$ \\
\hline Wheat germ & Triticum vulgare & WGA & $\begin{array}{l}\text { (GlcNAC)n: } \\
\text { NeuNAC }\end{array}$ & GlcNAC \\
\hline Castor bean & Ricinus communis & $\mathrm{RCA}$ & Gal & Gal \\
\hline Gorse & Ulex europeus & $\mathrm{UEA}_{1}$ & $\alpha$-L-FuC & $\alpha-L-F u C$ \\
\hline Horsegram & Dolichos biflorus & DBA & Gal NAC & Gal NAC \\
\hline Jackbean & Canavalia ensiformis & CONA & Man;Glc & $\alpha-\mathrm{MM}$ \\
\hline Peanut & Arachis hypogaea & PNA & $\begin{array}{c}\text { Gal-GalNAc } \\
>\text { Gal }\end{array}$ & Gal \\
\hline
\end{tabular}

" $\alpha$-L-Fuc $\alpha$-L-fucose; $\alpha-M M \alpha$-methyl-mannoside; Gal NAc N-acetylgalactosamine; Glc Glucose; Glc NAC N-acetylglucosamine: Man Mannose: NeuNAC N-acetyl-neuraminic acia (sialic acid). All sugars are $\beta$-D configurations unless otherwise stated. To inhibit fluorescein isothiocyanate-conjugated (FITC)-lectin binding, the indicated sugars were used at $0.2 \mathrm{M}$ with the exception of the inhibition of FITC-PNA binding, which required $0.3 \mathrm{Gal}$ (13) tiated mucosal biopsies from patients with celiac sprue. The observations indicate that unique labelling patterns for individual lectins are present in the small intestine and that cellular differences in both membrane and mucin glycoconjugates likely reflect differences in the degree of epithelial cell differentiation.

\section{MATERIALS AND METHODS}

Patients and biopsies: Small intestinal biopsies from 16 adult patients with untreated celiac sprue and six normal controls were used. The clinical details from each patient are summarized in Table 1. The clinical features of patients 1 to 3 were described in earlier reports (7-9), while biopsies from some patients have been used for other studies (10-12). Except for patients 3 and 6, all had diarrhea and weight loss. Patient 3 initially presented with a perforated small intestinal ulcer due to lymphoma and was later proven to have celiac sprue (9). Patient 6 initially presented with iron deficiency anemia alone with no diarrhea. All controls were investigated for diarrhea with no cause found; all had normal small intestinal biopsies.

All biopsies were obtained using a Rubin multipurpose suction biopsy instrument (Quinton Instruments, Washington) or under direct vision using an Olympus fiberoptic gastroscope (Carsen). Each biopsy was routinely fixed in Bouin's solution and processed, embedded in paraffin and serially sectioned at $5 \mu \mathrm{m}$. Serial sections were examined by routine light microscopy following staining with hematoxylin and eosin.

Lectin labelling: Deparaffinization and sequential washes in 95, 80 and 70\% alcohols to $0.01 \mathrm{M}$ phosphate buffered saline ( $\mathrm{pH}$ 7.4) was followed by lectin labelling as previously described (13, 14). Fluorescein isothiocyanate-conjugated (FITC) lectins (Vector Laboratories, California) were used as previously described (14). Table 2 shows the lectins used, their major sugar specificities and the bindings inhibitor used. For each different lectin, a solution of the same lectin concentration containing the sugar hapten inhibitor at a con- 
centration of $0.2 \mathrm{M}$ was used on adjacent control sections (13). Following preparation, observations were recorded using a Zeiss epifluorescence photomicroscope (Carl Zeiss, Germany).

To describe further a lectin labelling reactivity, a semiquantitative scheme of grading fluorescence intensity was used as reported previously (13) to permit expression of the histochemical data in tabular form. An absence of detectable fluorescence was expressed as 0 , trace fluorescence as $1+$ and increasing intensities of fluorescence as $2+$ to $4+$.

\section{RESULTS}

All patients and controls showed positive staining with each fluoresceinconjugated lectin used, and biopsies from all patients showed positive labelling of the surface epithelium and/or goblet cell mucins. Adjacent control sections with inhibitor sugar were uniformly negative for each lectin studied. Results are described below; grading of fluorescence intensity is tabulated in Tables 3 and 4.

Triticum vulgare: Intense labelling of the luminal epithelial cell surface and goblet cells from the base to the top of the villus was observed in biopsies from normal controls (Figure 1). Trace fluorescence or an absence of fluorescence was observed in the crypt regions. In contrast, celiac specimens showed labelling of both the luminal epithelial cell surface and goblet cell mucus from the basal to apical regions of crypts (Figure 2). In both control and celiac biopsies, a gradient of fluorescence intensity for both the luminal epithelial cell surface and goblet cell mucin was observed. The intensity of fluorescence appeared to increase from the base of the crypts to the luminal aspect of the biopsies for both control and celiac patients. Increasingly, the luminal cell surface and goblet cell of the crypts in celiac biopsies labelled more intensely than the same region in control biopsies $(\mathrm{P}<0.05)$.

Ricimus communis: Intense labelling of the luminal epithelial cell surface and goblet cells of control villi were observed while the crypt regions showed only limited or an absence of fluorescence, especially on the luminal cell
TABLE 3

Cell surface labelling

\begin{tabular}{lccccc}
\hline \multirow{2}{*}{ Lectin } & \multicolumn{3}{c}{ Controls $(\mathrm{n}=6)$} & \multicolumn{2}{c}{ Celiacs $(\mathrm{n}=16)$} \\
\cline { 2 - 6 } WGA & Crypt base & Crypt apex & Villus & Crypt base & Crypt apex \\
\cline { 2 - 6 } & $0-1+$ & $0-4+$ & $1-4+$ & $0-3+$ & $3-4+$ \\
RCA & $(0.2 \pm 0.1)$ & $(1.8 \pm 0.6)$ & $(2.7 \pm 0.4)^{*}$ & $(1.8 \pm 0.2)$ & $(3.8 \pm 0.1)^{*}$ \\
& $0-3+$ & $2-4+$ & $2-4+$ & $0-3+$ & $1-3+$ \\
UEA & $(2.0 \pm 0.4)$ & $(3.0 \pm 0.3)$ & $(3.0 \pm 0.3)^{*}$ & $(1.6 \pm 0.2)$ & $(2.3 \pm 0.2)^{*}$ \\
& $0-3+$ & $0-4+$ & $1-4+$ & $0-4+$ & $0-4+$ \\
DBA & $(1.3 \pm 0.4)$ & $(1.5 \pm 0.5)$ & $(2.0 \pm 0.5)^{*}$ & $(3.5 \pm 0.5)$ & $(3.6 \pm 0.3)$ \\
& $0-1+$ & $0-2+$ & $0-2+$ & $0-2+$ & $0-3+$ \\
CON A & $(0.2 \pm 0.2)$ & $(0.5 \pm 0.3)$ & $(0.8 \pm 0.4)$ & $(0.4 \pm 0.2)$ & $(0.9 \pm 0.3)$ \\
& $0-1+$ & $1-3+$ & $2-3+$ & $0-1+$ & $1-3+$ \\
& $(0.2 \pm 0.2)$ & $(1.6 \pm 0.4)$ & $(2.4 \pm 0.3)^{*}$ & $(0.1 \pm 0.1)$ & $(1.6 \pm 0.2)^{*}$ \\
\hline
\end{tabular}

Range of observations from 0 to 4 with a mean \pm SEM for patient group in parentheses. For PNA. consistent labelling was not present. See text for grading schema. " $P<0.05$ compared with crypt base

TABLE 4

Goblet cell labelling

\begin{tabular}{lccccc}
\hline & \multicolumn{3}{c}{ Controls $(n=6)$} & \multicolumn{2}{c}{ Celiacs $(n=16)$} \\
\cline { 2 - 5 } Lectin & Crypt base & Crypt apex & Villus & Crypt base & Crypt apex \\
\hline WGA & $0-1+$ & $0-3+$ & $1-4+$ & $0-3+$ & $1-4+$ \\
& $(0.2 \pm 01)$ & $(1.7 \pm 0.4)$ & $\left((2.7 \pm 0.3)^{*}\right.$ & $(1.1 \pm 0.2)$ & $(3.6 \pm 0.2)^{*}$ \\
RCA 1 & $0-2+$ & $2-4+$ & $2-4+$ & $0-1+$ & $3-4+$ \\
& $(0.5 \pm 0.3)$ & $(2.7 \pm 0.3)^{*}$ & $(2.7 \pm 0.3)^{*}$ & $(0.2 \pm 0.1)$ & $(3.3 \pm 0.1)^{*}$ \\
UEA & $0-1+$ & $1-3+$ & $1-3+$ & $0-3+$ & $1-4+$ \\
& $(0.3 \pm 0.2)$ & $(1.5 \pm 0.4)^{*}$ & $(1.5 \pm 0.4)^{*}$ & $(1.1 \pm 0.3)$ & $(2.7 \pm 0.3)$ \\
DBA & $0-1+$ & $0-3+$ & $0-3+$ & $0-2+$ & $0-2+$ \\
& $(0.2 \pm 0.2)$ & $(1.5 \pm 0.5)$ & $(1.5 \pm 0.5)$ & $(1.1 \pm 0.2)$ & $(0.8 \pm 0.2)$ \\
CONA & $0-1+$ & $0-1+$ & $0-1+$ & $0-1+$ & $0-3+$ \\
& $(0.2 \pm 0.2)$ & $(0.4 \pm 0.2)$ & $(0.4 \pm 0.2)$ & $(0.1 \pm 0.1)$ & $(1.3 \pm 0.4)^{*}$ \\
\hline
\end{tabular}

Range of observations from 0 to 4 with mean \pm SEM for patient group in parentheses. For PNA, consistent labelling was not present. See text for grading schema. ${ }^{*}<0.05$ compared with crypt base

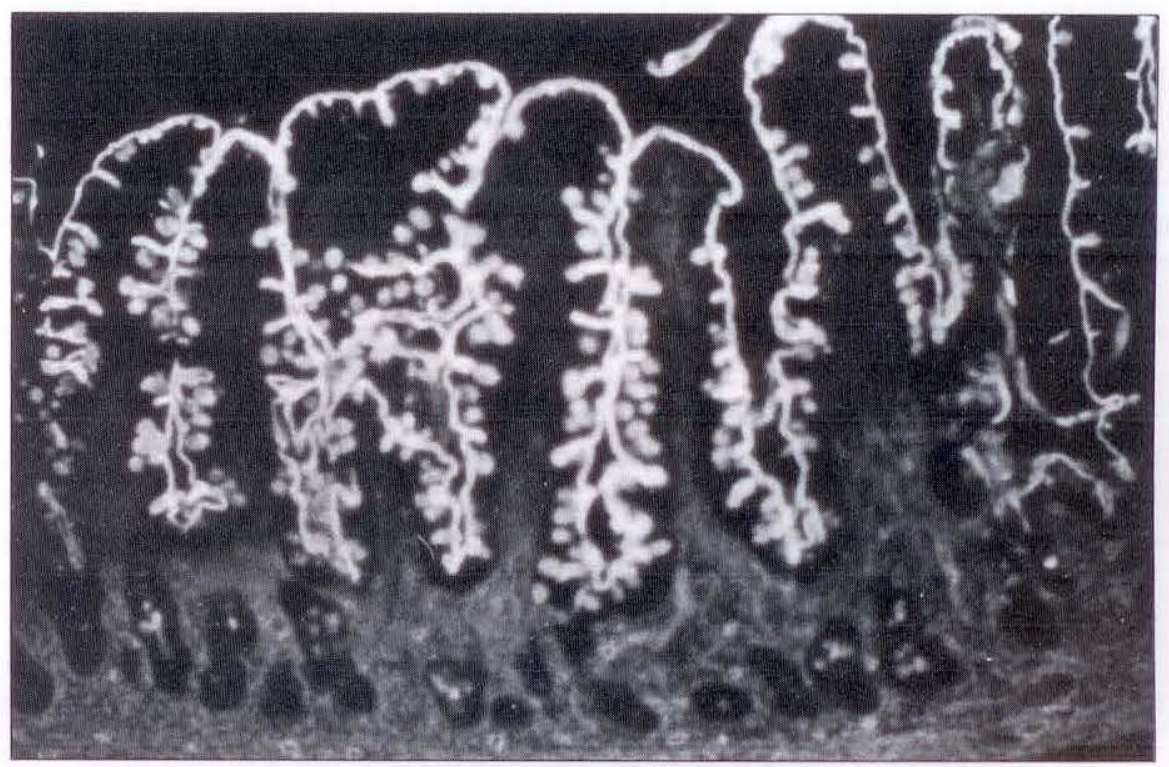

Figure 1) Fluorescein isothiocyanate-conjugated-Triticum vulgare labelling of normal duodenum. Cell surface and goblet cell labelling shows increasing intensity of fluorescence from the crypt to villus regions. Only trace fluorescence is present in the crypt region, mainly at the crypt apex 


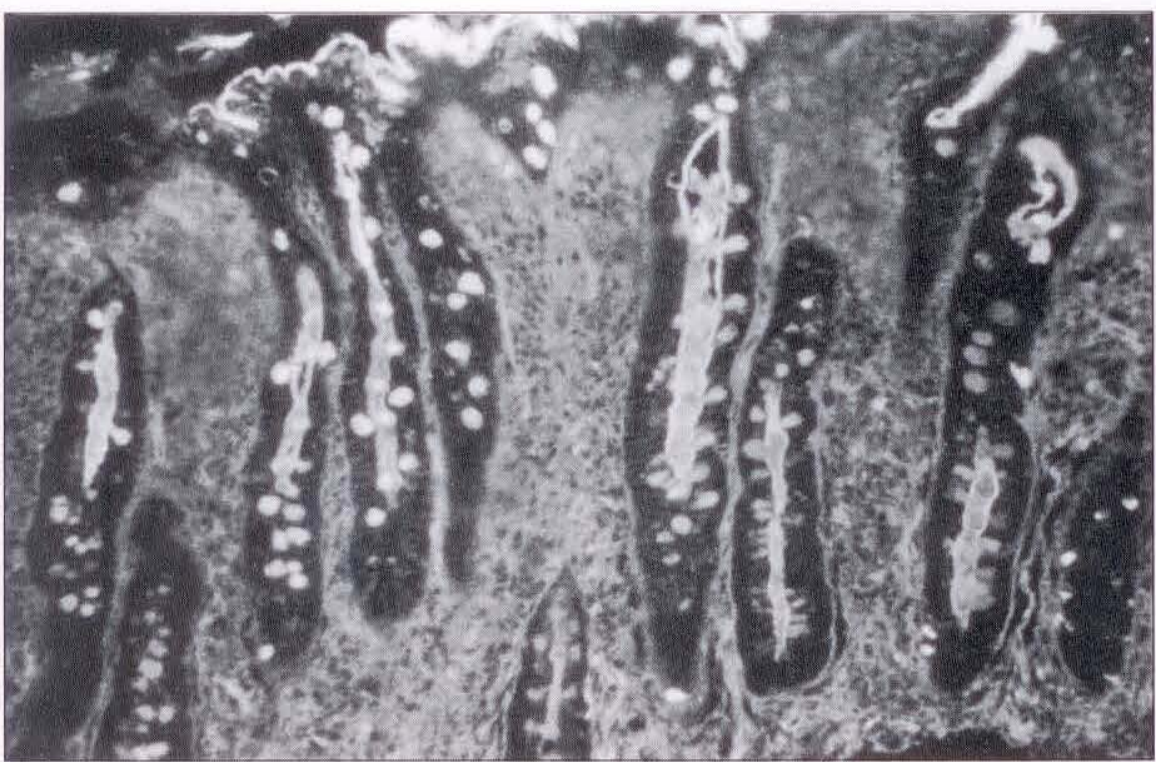

Figure 2) Fluorescein isothiocyanate-conjugated-Triticum vulgare labelling of expanded crypt region in duodenal biopsy from a celiac patient. Fluorescence is more intense compared with the crypt regions in controls (seen in Figure 1) and a gradient of increasing fluorescence intensity for both cell surface and goblet cell labelling is present within crypt regions

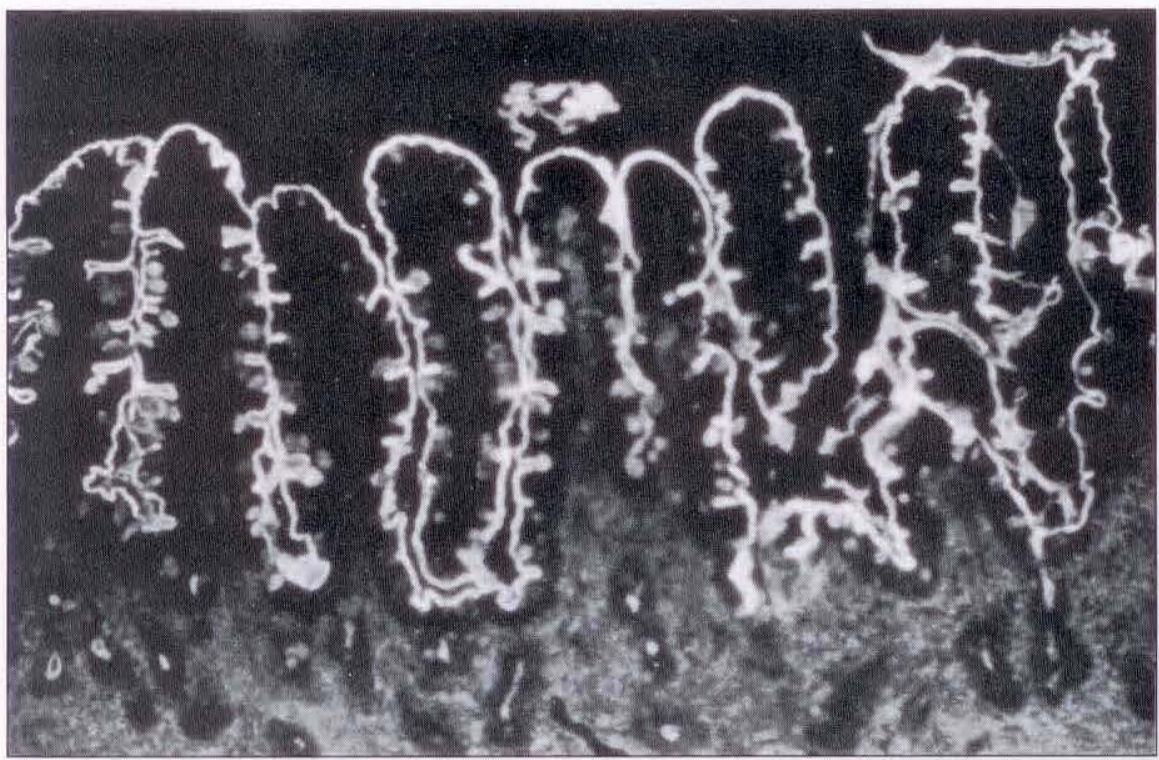

Figure 3) Fluorescein isothiocyanate-conjugated-Ricinus communis labelling of normal duodenum. Cell surface and goblet cell labelling is most in the villus region

surface (Figure 3). In contrast, celiac biopsies showed both luminal epithelial cell surface and goblet cell labelling from the basal to apical regions of the biopsies (Figure 4). In both control and celiac biopsies, a similar gradient of fluorescence intensity for both the luminal epithelial cell surface and goblet cell mucin was observed. The intensity of fluorescence appeared to increase from the base of the crypts to the most luminal aspect of the biopsies in both control and celiac patients. This differential gradient of fluorescence intensity appeared to be less for celiac than control biopsies.

Ulex europeus: For control biopsies, fluorescence was present in goblet cells and along the luminal epithelial cell surface with a differential binding gradient from the base of crypts to the top of villi (Figure 5). In contrast, celiac

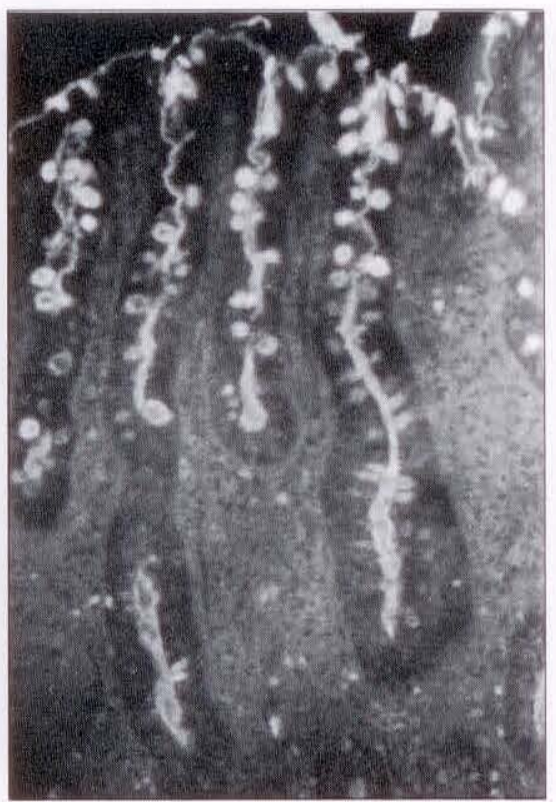

Figure 4) Fluorescein isothiocyanate-conjugated-Ricinus communis labelling of expanded crypt region in duodenal biopsy from a celiac patient. A gradient of fluorescence intensity within the crypt is present

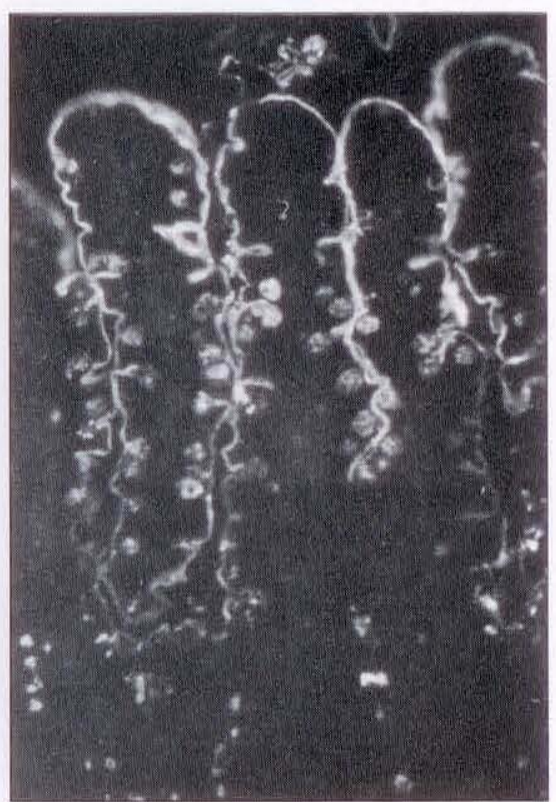

Figure 5) Fluorescein isothiocyanate-conjugated (FITC)-Ulex europeus labelling of normal duodenum. Cell surface and goblet cell labelling is present although not as intense as for FITC-Triticum vulgare or FITC-Ricinus communis

biopsies showed intense latelling of the luminal cell surface and goblet cells with little or no detectable binding gradient present (Figure 6).

Dolichos biflorus, Canavalia ensiformis and Arachis hypogaea: Biopsies from 
controls and celiacs showed only minimal fluorescence labelling in goblet cells and along the luminal cell surface for FITC-D biflorus and FITC-C ensiformis. In some biopsies, labelling of the luminal cell surface was variable or not present. For FITC-A hypogaea, only traces of labelling of the luminal cell surface in the villus - but not crypt regions - were present in some, but not all, biopsies. Goblet cell mucin did not label except for trace labelling in the supranuclear regions of the epithelial cell as described elsewhere (13).

\section{DISCUSSION}

A novel histochemical approach was used in the present investigation to label specific sugar residues in the small intestinal epithelium. Lectins are naturally occurring proteins, derived mainly from plants (1), that can bind to epithelial cell membrane surfaces and goblet cells of rats and humans $(13,15$, 16). Distinct labelling patterns for each lectin in both control and celiac biopsies were evident, reflecting the unique topographic distribution of specific carbohydrate components in complex cell membrane proteins known to be present in human small intestine.

Striking differences in fluorescence intensity along the crypt-villus column were also evident in these studies in both control and celiac biopsies, reflecting the presence of a gradient in the topographic distribution of specific lectin binding sites in small intestinal epithelial cells with increasing enterocyte differentiation. This is consistent with the concept that epithelial cells migrate from the crypt to villus region and, as enterocytic differentiation as well as maturation occurs, sugar residues are sequentially added to form completed oligosaccharide side chains $(17-20)$. This differentiation process occurs in normal small intestinal epithelium and (as shown in this study) in adult celiac epithelium.

In the adult celiac, however, the topographic distribution of lectin binding sites was unique and differed from control biopsies, indicating that the differentiation process in celiac enterocytes, although present, is altered substantially. Although previous studies

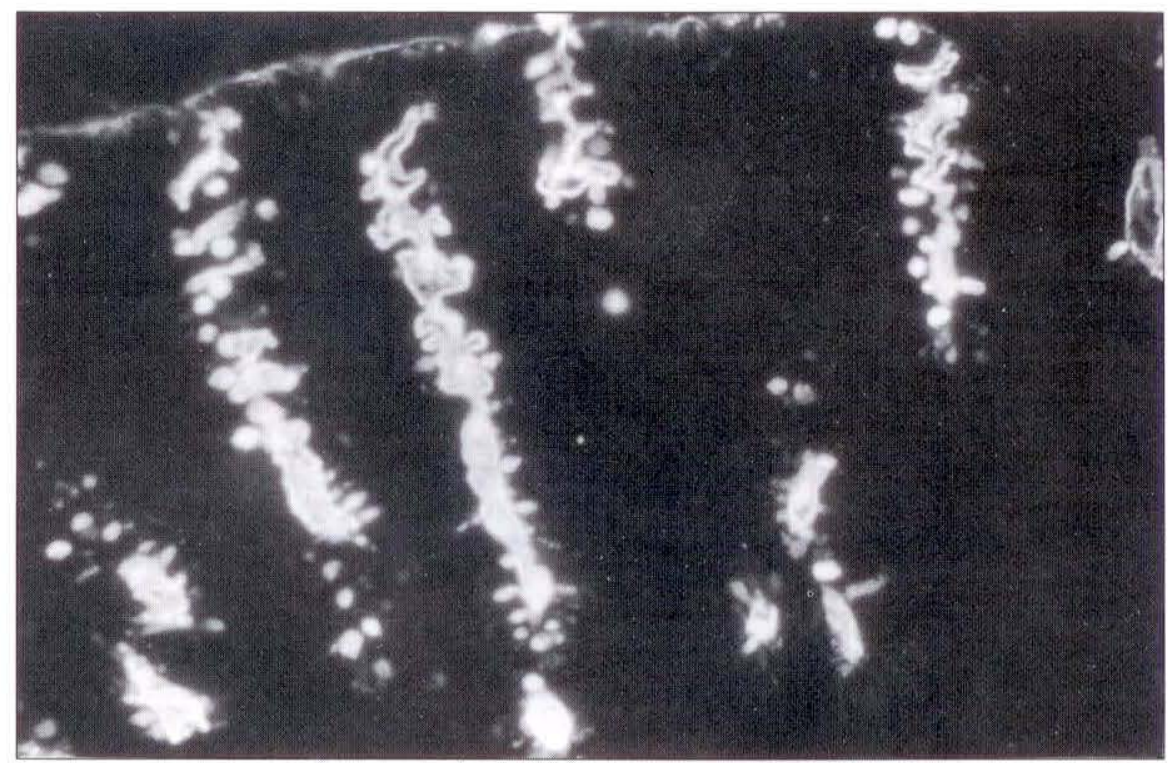

Figure 6) Fluorescein isothiocyanate-conjugated-Ulex europeus labelling of expanded crypt region in duodenal biopsy from celiac patient. Cell surface and goblet cell fluorescence is increased compared with controls (Figure 5)

have explored labelling differences in lectin binding to the microvillus surfaces in children with celiac diseases $(21,22)$, these investigations, including the present report, have not determined if these observations are specific for this disorder. A nonspecific alteration in the enterocyte differentiation process could result from any form of injury or toxicity that alters the structure of the small intestine. Additional studies - possibly employing biopsies from other small intestinal disorders that result in a 'flat' villus lesion (eg, tropical sprue, soy protein enteropathy, microvillus inclusion disease, etc) might further define the specificity of the labelling changes recorded in the present investigation.

A clear understanding of the pathogenesis of celiac sprue remains elusive. Presumably, in genetically predisposed individuals, gluten (or one of its components) provokes a toxic reaction, mainly in the proximal small intestine, possibly by binding to intestinal surface structures. It has been suggested that deficiency of intestinal peptidase activity results in toxic gluten degradation products that bind to surface structures and induce immunoregulatory pathomechanisms. Alternatively, a primary immune defect may be responsible.
Others (23) have hypothesized that gluten acts as a lectin and binds to specific oligosaccharide structures of glycoproteins or glycolipids in the intestinal brush border leading to cell toxicity. Some evidence has accumulated to support this gluten-lectin hypothesis in the pathogenesis of celiac disease. Gliadin and gluten peptides behave like lectins and have been shown to bind to high mannose-type glycoproteins in human serum as well as immature crypt cells in rat intestine $(24,25)$. Moreover, gliadin peptides from bread wheat may reversibly agglutinate poorly differentiated human $\mathrm{K} 562$ (S) cells; binding and agglutinating activity was apparently inhibited by mannan, a mannose polysaccharide and $\mathrm{N}$-acetyl-glucosamine (26). Finally, mannan and oligomers of $\mathrm{N}$-acetylglucosamine were recently reported to exhibit protective effects to gliadin in vitro using cultured small intestinal biopsies from children with active celiac disease (27). This intriguing observation still requires in vivo examination. Although the present study has shown that the numerous small intestinal binding sites for lectins are present in adult celiacs, a carbohydrate receptor - specific to celiac disease that could bind gliadin requires elucidation. 
ACKNOWLEDGEMENTS: Research support provided by Medical Research Council of Canada, Ottawa, Ontario, and technical support by Michael McCann.

\section{REFERENCES}

1. Lis H, Sharon N. The biochemistry of plant lectins (phytohemagglutinins). Ann Rev Biochem 1973;42:541-74.

2. Nachbar MS, Oppenheim JD. Lectins in the United States diet: A survey of lectins in commonly consumed foods and a review of the literature. Am J Clin Nutr 1980;33:2238-45.

3. Brady PG, Vannier AM, Banwell JG. Identification of the dietary lectin, wheat germ agglutinin, in human intestinal contents. Gastroenterology 1978;75:236-9.

4. Trier JS. Celiac sprue. N Engl J Med 1992;325:1709-19.

5. Weiser MM, Douglas AP. An alternative mechanism for gluten toxicity in coeliac disease. Lancet 1976;i:567-9.

6. Ament ME, Rubin CE. Soy protein another cause of the flat intestinal lesion. Gastroenterology 1972;62:227-34.

7. Scholey J, Freeman HJ. Celiac sprue associated immune complex glomerulonephritis. J Clin Gastroenterol 1986;8:181-3.

8. Freeman HJ, Chiu BK. Small bowel malignant lymphoma complicating celiac sprue and the mesenteric lymph node cavitation syndrome. Gastroenterology 1986;90:2008-12.

9. Freeman HJ, Chiu BK. Multifocal small bowel lymphoma and latent celiac sprue. Gastroenterology 1986;90:1992-7.

10. Buchan AMJ, Grant S, Brown JC, Freeman HJ. A quantitative study of enteric endocrine cells in celiac sprue.
J Pediatr Gastroenterol Nutr 1984;3:665-71.

11. Wolber R, Owen D, DelBuono L, Appelman H, Freeman H.

Lymphocytic gastritis in patients with celiac sprue or spruelike intestinal disease. Gastroenterology 1990;98:310-5.

12. Wolber R, Owen D, Freeman H. Colonic lymphocytosis in patients with celiac sprue. Hum Pathol 1990;21:1092-6.

13. Freeman HJ, Lotan R, Kim YS. Application of lectins for detection of goblet cell glycoconjugate differences in proximal and distal colon of the rat. Lab Invest 1980;42:405-12.

14. Freeman H]. Lectin histochemistry of 1,2-dimethylhydrazine-induced rat colon neoplasia. J Histochem Cytochem 1983;31:1241-5.

15. Etzler ME, Branstrator ML. Differential localization of cell surface and secretory components in rat intestinal epithelium by use of lectins. J Cell Biol 1974;62:329-43.

16. Jacobs LR, De Fontes D, Cox KL. Cytochemical localization of small intestinal glycoconjugates by lectin histochemistry in controls and subjects with cystic fibrosis. Dig Dis Sci 1981:28:422-8.

17. Weiser MM. Intestinal epithelial cell membrane glycoprotein synthesis. I. An indicator of cellular differentiation. J Cell Biol 1973;248:2536-41.

18. Weiser MM. Intestinal epithelial cell membrane glycoprotein synthesis. II. Glycosyltransferasess and endogenous acceptors of the undifferentiated cell surface membrane. J Biol Chen 1973;248:2542-8.

19. Bourhours JF, Glickman RM. Rat intestinal glycolipids. II. Distribution and biosynthesis of glycolipids and ceramide in villus and crypt cells. Biochim Biophys Acta
1976;441:123-33.

20. Kim YS, Perdomo J, Ochoa P, Isaacs RA. Regional and cellular localization of glycosyltransferases in rat small intestine. Changes in enzymes with differentiation of intestinal epithelial cells. Biochin Biophys Acta 1975;391:39-50.

21. Vasmant D, Feldmann G, Fontaine JL. Ultrastructural localization of Concanavalin A surface receptors on brush-border enterocytes in normal children and during coeliac disease. Pediatr Res 1982;16:441-5.

22. Barresi G, Tuccari G, Tedeschi A, Magazzu G. Lectin binding sites in duodeno-jejunal mucosae from coeliac children. Histochemistry 1988;88:105-12.

23. Weiser MM, Douglas AP. An alternative mechanism for gluten toxicity in coeliac disease. Lancet 1976;i:567-9.

24. Kottgen E, Volk B, Kluge F, Gerok W Gluten, a lectin with oligomannosyl specificity and the causative agent of gluten-sensitive enteropathy. Biochem Biophys Res Comm 1982;109:168-7-3.

25. Kottgen E, Kluge F, Volk B, Gerok W. The lectin properties of gluten as the basis of the pathomechanism of gluten-sensitive enteropathy. Klin Wochenschr 1983;61:111-2.

26. Auricchio S, De Ritis G, De Vincenzi $\mathrm{M}$, et al. Agglutinating activity of gliadin-derived peptides from bread wheat: Implication for coeliac disease pathogenesis. Biochem Biophys Res Comm 1982;109:168-73.

27. Auricchio S, De Rites G, De Vicenzi et al. Mannan and oligomers of $\mathrm{N}$-acetylglucosamine protect intestinal mucosa of celiac patients with active disease from in vitro toxicity of gliadin peptides. Gastroenterology 1990;99:973-8. 


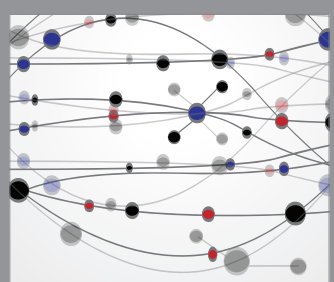

The Scientific World Journal
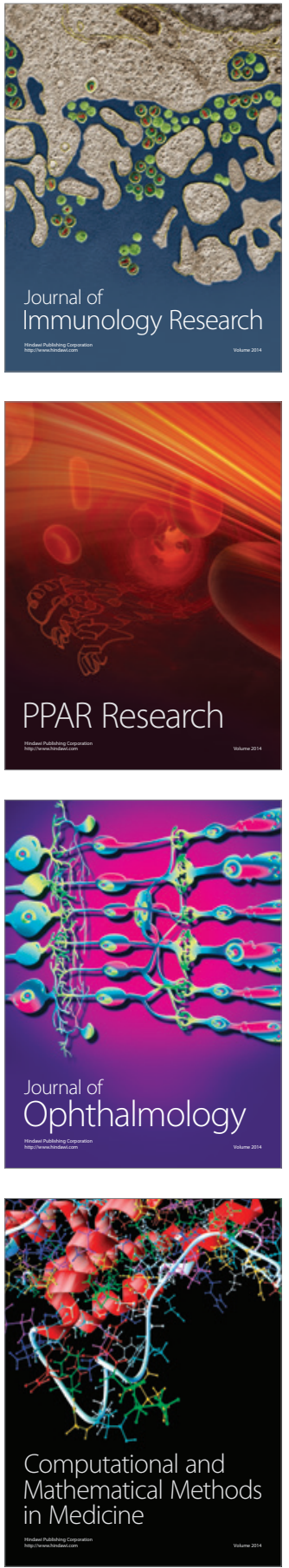

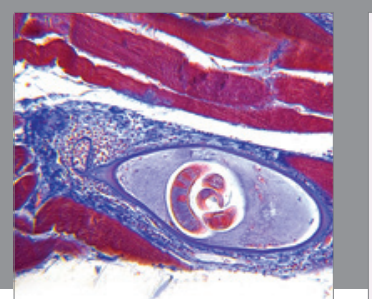

Gastroenterology Research and Practice

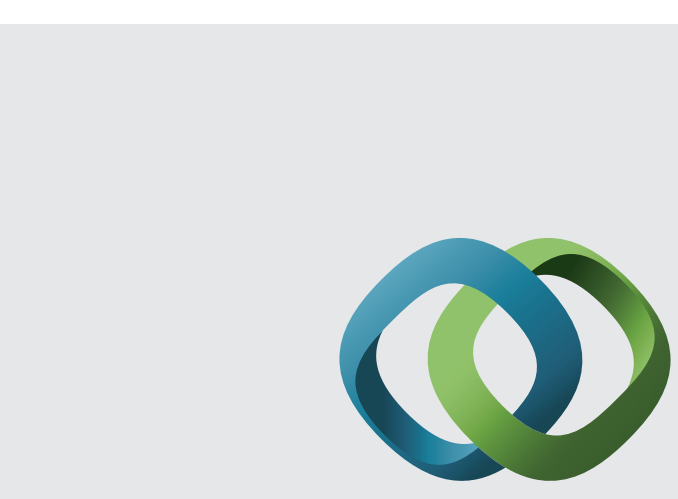

\section{Hindawi}

Submit your manuscripts at

http://www.hindawi.com
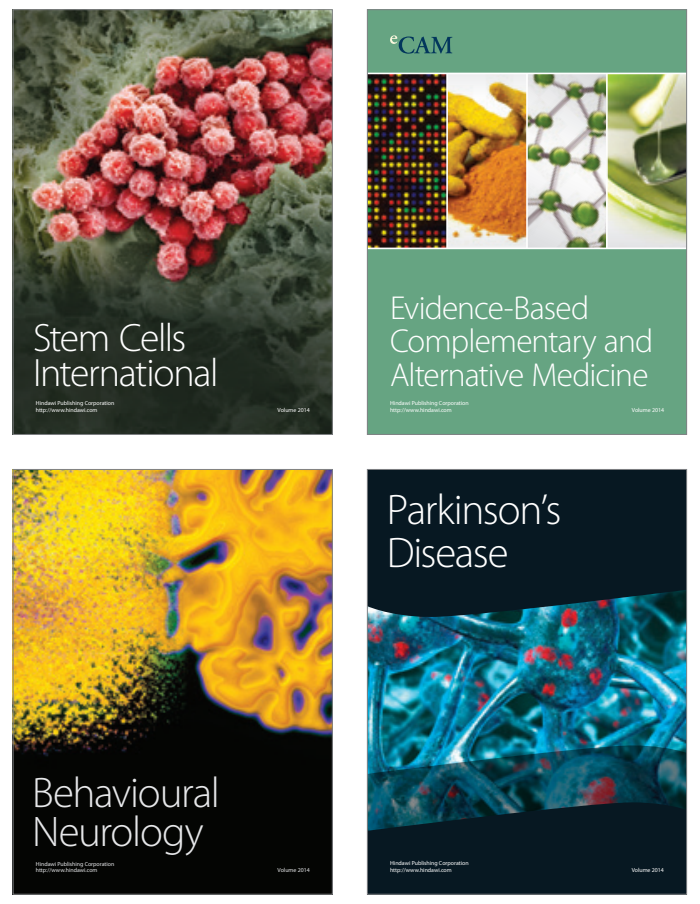
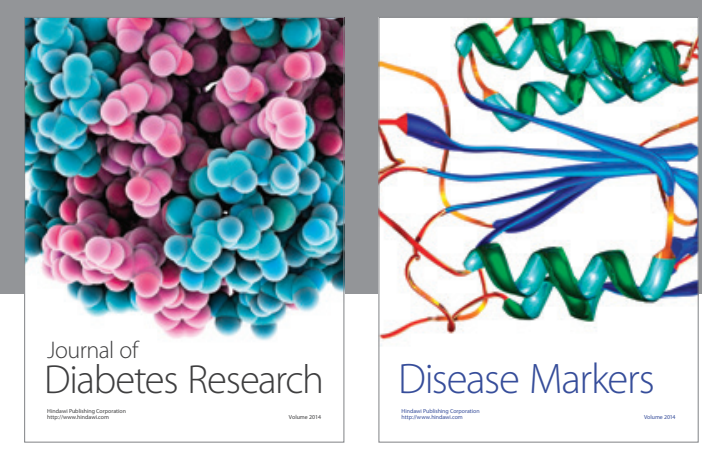

Disease Markers
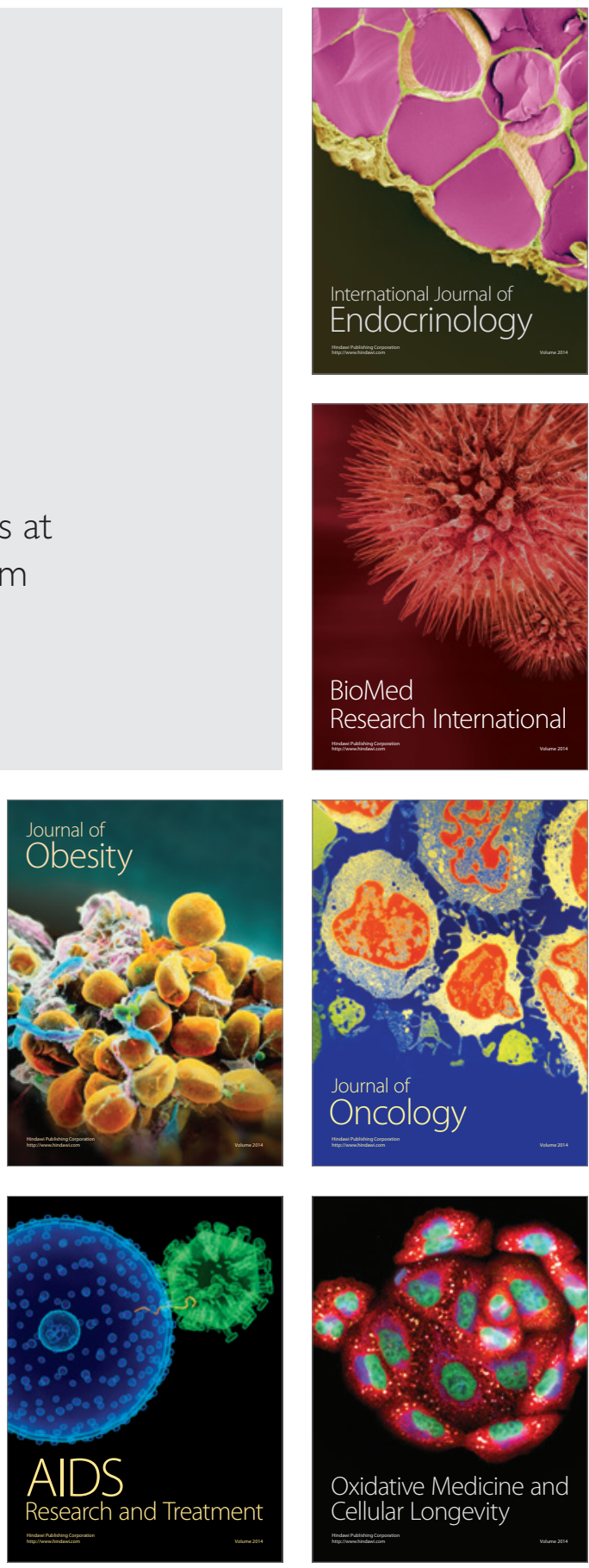